\title{
THE LINK BETWEEN FINANCIAL TRANSPARENCY AND KEY FINANCIAL RATIOS: A CASE FROM TURKEY
}

\author{
DOI: 10.17261/Pressacademia.2018.940 \\ JEFA- V.5-ISS.3-2018(9)-p.321-327
}

\section{Burcu Adiloglu', Nevzat Gungor², Goksel Yucel ${ }^{3}$}

${ }^{1}$ Istanbul University, Avcılar Campus, Faculty of Business Administration, Accounting Department, Istanbul, Turkey. adiloglu@istanbul.edu.tr, ORCID: 0000-0001-9680-1408

${ }^{2}$ Istanbul University, Avcilar Campus, Faculty of Business Administration, Accounting Department, Istanbul, Turkey. nevzat.gungor@istanbul.edu.tr, ORCID: 0000-0001-9883-1985

${ }^{3}$ Istanbul University, Avcılar Campus, Faculty of Business Administration, Accounting Department, Istanbul, Turkey. gokselyucel@istanbul.edu.tr, ORCID: 0000-0003-1940-8789

Date Accepted: September 12, 2018

To cite this document

Adiloglu, B., Gungor, N., Yucel, G. (2018). The link between financial transparency and key financial ratios: a case from Turkey. Journal of Economics, Finance and Accounting (JEFA), V.5(3), p.321-327.

Permemant link to this document: http://doi.org/10.17261/Pressacademia.2018.940

Copyright: Published by PressAcademia and limited licenced re-use rights only.

\section{ABSTRACT}

Purpose- Since globalization movements in the capital markets change the information requirements expected from the financial statements to a great extent today, companies tend to provide more reliable, transparent and quality financial and non-financial information within the framework of corporate transparency. These trends also affect the financial reporting processes especially financial disclosures. The purpose of this study is to evaluate disclosures that are essential to an investor's understanding and analysis of the economics underlying the information in financial reports.

Methodology- It focuses on relationship between financial transparency and key financial ratios. In order to reach this aim financial transparency and disclosure checklist is established and companies are classified according to their transparency levels. Using a sample of publicly traded companies from BIST 100 (excluding finance sector) for the year 2016, Standard \& Poor's (S\&P) methodology is applied for assessment of financial transparency and disclosure (T\&D) levels based on their annual reports and websites.

Findings- The results reveal that transparency level has statistical differences among the group means of some key financial ratios. High quality disclosure also means more accountable and transparent companies for investors.

Conclusion- The study also evaluates the relationship between the firm-specific T\&D scores and financial performance of BIST 100 firms. This paper sufficiently contributes towards literature on financial disclosures. High quality disclosure has significant influence on investors and lenders who must assess risks and returns and decide where to place their money best, strengthen the efficiency of capital allocation as well as offer the benefit of reducing the costs of capital.

Keywords: Financial statements, financial ratios, financial transparency, disclosure, Borsa Istanbul (BIST) 100. JEL Codes: M41, M40, G30

\section{INTRODUCTION}

After many financial scandals of European and American companies in 2000's (Enron, Tyco, Parmalat and etc.) the issue of voluntarily disclosure and transparency in a financial reporting process led a deep interest from the view of investors. After these scandals many regulations and voluntarily disclosures took a part in today's financial reporting. Today financial reporting is a deep concept beyond the disclosure of financial statements. Attention of investors has turned to not only the effectiveness of corporate governance practices but also to transparency and disclosure of information.

Corporate governance refers to the quality, transparency, and dependability of the relationships between the shareholders, board of directors, management, and employees that define the authority and responsibility of each in delivering sustainable value to all the stakeholders. Transparency is clearly linked to the debate about governance reform, as it embodies one of the core principles corporate governance. It is presented as an overarching cornerstone of the OECD 
corporate governance guidelines: "Investor confidence and market efficiency depend on the disclosure of accurate timely information about corporate performance. To be of value in the global capital markets, disclosed information should be clear, consistent and comparable" (OECD,1998)

Corporate Governance Principles developed by OECD in 1999, then updated in 2004 and the 2015 revision of the Principles of Corporate Governance adresses these and other emerging issues that are increasingly relevant.

Standard \& Poor's has a study that examines the transparency and disclosure (T\&D) practices of major public companies around the globe. Since T\&D are fundamental components of corporate governance greater transparency and better disclosure keep corporate stakeholders better informed about the way a company is being managed. In addition, studies suggest that better disclosure has a positive impact on the efficient functioning of capital markets.

Corporate transparency is defined as the widespread availability of relevant, reliable information about the periodic performance, financial position, investment opportunities, governance, value, and risk of publicly traded firms. This why the issue of transparency is so important while measuring the financial performance.

In this study in order to examine the relationship between the transparency level and the financial performance indicators of Turkish companies a transparency checklist is established by using Standard \& Poor's study. The rest of the paper is organized as follows: Section 2 provides a detailed survey of past studies. Section 3 explains the data (variables employed) and methodology while the results are presented in Section 4. Finally, Section 5 gives the conclusion.

\section{LITARATURE REVIEW}

Sandeep et al. (2002) use a dataset to examine Transparency \& Disclosure scores (T\&D score) in 19 emerging markets for 354 firms representing $70 \%$ of S\&P/IFCI Index market capitalization over the 3 years ending in 2000. For 3 years, the differences between countries, economic sectors and trends are analyzed. The study finds that emerging markets in Asia and South Africa have significantly greater transparency and clarity compared to emerging markets in Latin America, Eastern Europe and the Middle East.

Aksu \& Kosedag (2006) evaluate the T\&D practices of the 52 biggest firms in the Istanbul Stock Exchange (ISE), hinge on their English and local language annual reports and websites. Standard \& Poor's (S\&P) scoring methodology is used which is customised version of the 98 desirable T\&D attributes they used in several other countries. The results of the paper provide considerable support for prior findings in developed markets, they also provide an insight on how specific agency problems faced by ISE firms impact their T\&D scores.

Madhani (2007), discusses the role of voluntary disclosure and transparency in financial reporting and highlights risks and costs associated with voluntary disclosure. The study claims that, voluntary disclosure practices increase investor awareness and trust, reducing the uncertainty of the returns to the capital suppliers which is expected to reduce the firm's cost of external capital to increase its value. Disclosure practices mitigate the political costs of non-compliance and reduce the risk of higher taxes, litigation and too much regulation.

Haat et al. (2008) examine the effect of good corporate governance practices on corporate transparency and performance of Malaysian listed companies. Sample consist of 75 companies listed on BMB in 2002 and hierarchical regression is applied to test the relationship between among corporate governance, transparency and performance. The results show that there is a significant negative relation between performance and audit quality. Furthermore, disclosure and timeliness are not significant contributing factors in the relationship between corporate governance and market performance.

Adiloglu \& Vuran (2012) investigate the transparency levels of financial information disclosures in corporate governance reports and annual reports are calculated by establishing a transparency checklist for the year 2010. Manova analysis is employed to investigate the relationship between the transparency levels and financial performance indicators. The results indicate that transparency level is statistically significant with return on asset, total debt / total assets, longterm debt / total assets and corporate governance index variables.

Arbatlı \& Escolano (2015) investigate whether financial transparency has an effect on market perceptions of sovereign risk or not. The results indicate that financial transparency has a positive and significant effect on ratings in advanced and developing economies, respectively - but its effect works through different channels in advanced and developing economies. In advanced economies, financial transparency is related with better financial outcomes, leading indirectly to higher credit ratings.

Sharif \& Lai (2015) examine the effects of disclosure in corporate governance practices on firm performance, bankruptcy risk, leverage and dividend policy in public listed companies. To measure disclosure and transparency more accurately, the recommended practices of the Malaysian Code on Corporate Governance 2012 (MCCG 2012) is used. The results show that corporate disclosure practices have positive effects on company performance and negative effects on company leverage. 
And also, the paper did not find any significant relationship between corporate transparency levels with bankruptcy risk and dividend payouts.

Achoki et al. (2016) examine general and strategic disclosure, financial disclosure, forward looking disclosure, social board disclosure as a proxy for measuring voluntary disclosure and firm characteristics and how they affect the financial performance of commercial banks in Rwanda. Return on Equity is used as financial performance measurement. Sample of the study consists of 14 commercial banks in Rwanda. The result of the paper indicates a positive relationship between financial, forward looking and board and social disclosure and return on equity.

Qui et al. (2016) investigate the link between a firm's environmental and social disclosures and its profitability and market value. The findings prove that there is relation between profitability and social disclosures and there is no relation between environmental disclosures and profitability. Furthermore, it is determined that firms with greater economic resources make more extensive disclosures which yield net positive economic benefits.

Torchia \&Calabrò (2016) examine the link between board of directors' structure and financial transparency and disclosure (T\&D). The paper analyses financial T\&D and board structure of Italian listed companies. Multiple linear regression analysis is applied. The results show a significant relation between board structure and the level of financial T\&D. Specifically, it is found a positive and significant relationship between the independent directors' ratio and the level of financial T\&D and a negative relationship between board size and the level of financial T\&D.

Akhigbe et al. (2017) analyze the relation between transparency and bank holding company (BHC) profit efficiency using these measures of transparency for 1996 through 2014. Their findings indicate that transparency has a positive effect on bank financial performance.

Zulfikar et al. (2017) aim to examine an independent commisioner against mandatory disclosure of financial performance as a moderating variable. The sample in this research includes 117 banking companies listed in Bank Indonesia during the years of 2013-2015. The statistical method used is Moderated Regression Analysis (MRA) with multiple linear analysis. Based on the statistical test, the results indicate that the independent commissioner negatively affects mandatory disclosure. The financial performance of independent commissioners strengthens such relationship.

Hadi et al. (2018) aim to analyze the effect of local government characteristic and accountability performance on the financial disclosure based on WEB-ICT and how it's implications for local government financial performance as a response to the public information disclosure requirements. 307 regencies and cities local government in Indonesia is selected as samples for the study. The result shows that local governments with better performance accountability levels and have greater or more mature characteristics will disclose wider financial information through the website. It indicates that local government characteristic and accountability of local government performance has a positive influence on financial disclosure based on web-ICT.

\section{DATA AND METHODOLOGY}

This study investigates relationship between the financial performance indicators and the transparency level of companies operating in manufacturing sector. Sample of this study comprise of the 64 largest manufacturing companies which are listed in BIST 100 index during the year 2016. Distribution of companies by sectors are shown in Figure 1.

Figure 1: Distrubution of Companies by Sectors

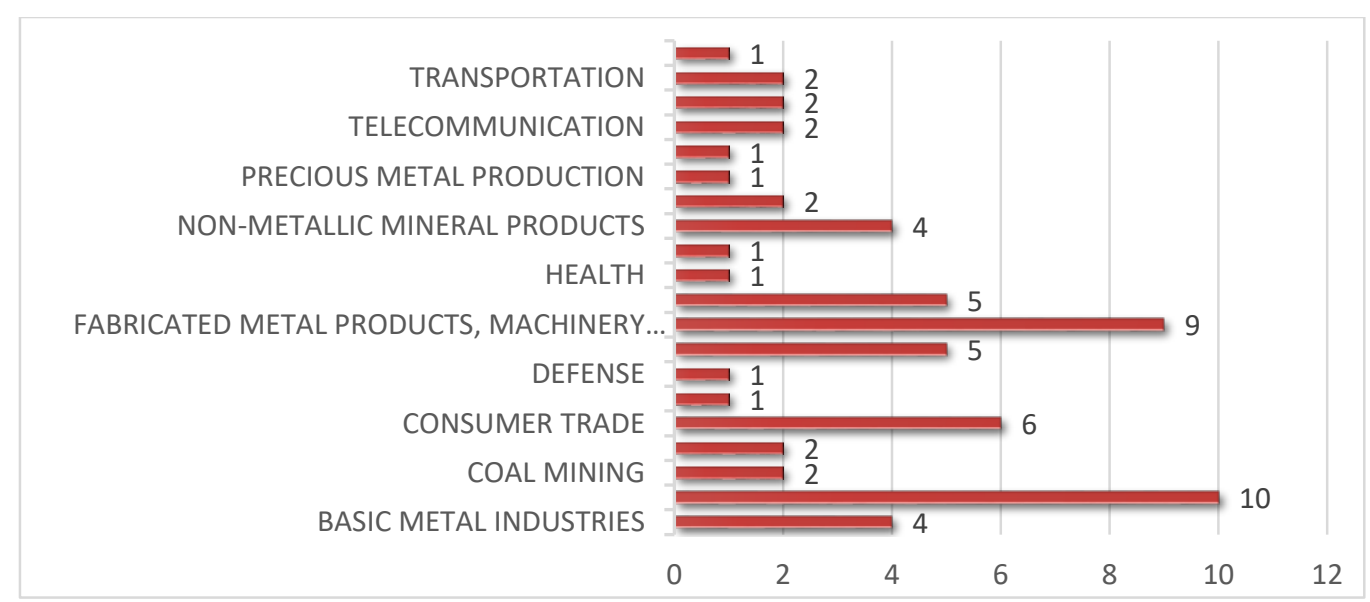


It focuses on sources of information that are most easily accessible by local and international investors which are the latest available English language and local language company annual reports and the English and Turkish web sites. In this context, the transparency levels of financial information disclosures in annual reports are calculated by creating a transparency checklist. In the transparency checklist, 17 criteria obtained from Standard \& Poor's scoring methodology.

If the relevant information in the annual report is determined, " 1 " is given to the company. On the contrary, the company gets " 0 " point. The points for each company are totalized and the transparency score is calculated by dividing total score to 17. After calculating this transparency level score of 64 companies, these companies are divided into 3 categories as shown in Table 1. MANOVA Analysis is conducted to investigate if there is a significant difference between means of at least one financial ratio of at least two groups of transparency categories.

Table 1: Category Diversification of Firms

\begin{tabular}{|l|l|l|l|}
\hline Category & Name of the Category & Transparency Level & \# of Companies \\
\hline 1 & Least Transparent & $48 \%-$-below & 26 \\
\hline 2 & Transparent & $49 \%-87 \%$ & 35 \\
\hline 3 & Most Transparent & $88 \%-100 \%$ & 3 \\
\hline
\end{tabular}

Financial performance indicators are calculated in order to analyze relationship between financial performance and transparency level of disclosure. The financial statements are gathered from the annual reports of selected companies. 8 financial performance indicators and 2 dummy variable (Corporate Governance Index, Sustainability Index), totally 10 dependent variables are shown in Table 2:

Table 2: Financial Performance Indicators Used in the Paper

\begin{tabular}{|l|l|}
\hline Financial Ratios & Financial Ratios \\
\hline Current Ratio & Return on Asset \\
\hline Acid-test Ratio & Debt to Equity \\
\hline Net Profit Margin & CFOA to Net Income \\
\hline Operating Margin & Sustainability Index \\
\hline Return on Equity & Corporate Governance Index \\
\hline
\end{tabular}

In order to evaluate group differences across the financial ratios simultaneously MANOVA (Multivariate Analysis of Variance) is employed by SPSS 21. Multivariate analysis of variance evaluates differences among centroids (composite means) for a set of dependent variables when there are two or more levels of an independent variables (groups) (Tabachnick et al., 2007). Manova analysis is applied in four steps:

- Multivariate tests: to test the basic assumption of Manova,

- Levene's Test of Equality of Error Variances: to test for equality of error variances across dependent variables,

- Test of Between-Subjects Effect: to investigate if the independent variable differ on all of the dependent measures,

- Post hoc tests: to test the significance of differences in levels of an independent factor in comparison to a dependent variable.

\section{FINDINGS AND DISCUSSIONS}

Table 3 involves the most commonly used multivariate tests (Pillai's Trace, Wilk's Lambda, Hotelling's Trace and Roy's Largest Root) and the basic hypothesis of Manova (the population means on the multiple dependent variables are equal across groups) is tested by the multivariate tests.

Table 3: Multivariate Tests

\begin{tabular}{|l|l|l|l|l|l|l|l|l|}
\hline Effect & Value & & F & Hypothesis df & Error df & Sig. & Partial Eta Squared \\
\hline Intercept & Pillai's Trace &, 846 & & $28,561 \mathrm{~b}$ & 10,000 & 52,000 &, 000 &, 846 \\
\hline & Wilks' Lambda &, 154 & & $28,561 \mathrm{~b}$ & 10,000 & 52,000 &, 000 &, 846 \\
\hline & Hotelling's Trace & 5,493 & & $28,561 \mathrm{~b}$ & 10,000 & 52,000 &, 000 &, 846 \\
\hline & Roy's Largest Root & 5,493 & $28,561 \mathrm{~b}$ & 10,000 & 52,000 &, 000 &, 846 \\
\hline TRANSPERANCY & Pillai's Trace &, 793 & 3,486 & 20,000 & 106,000 &, 000 &, 397 \\
\hline & Wilks' Lambda &, 349 & $3,606 \mathrm{~b}$ & 20,000 & 104,000 &, 000 &, 409 \\
\hline & Hotelling's Trace & 1,460 & 3,723 & 20,000 & 102,000 &, 000 &, 422 \\
\hline
\end{tabular}


Since the significance level of all tests are smaller than $5 \%$, each of the four measures indicate that there is a significant difference between the means of at least one dependent variable (financial ratio) of at least two groups of independent variable (transparency levels of firms).

Table 4 displays the results of Levene's test for equality of error variances across financial performance indicators. As it is seen in the table, it can be deduced that equal variances are assumed for variables with significance level >0,05.

Table 4: Levene's Test of Equality of Error Variances

\begin{tabular}{|l|l|l|l|l|}
\hline & F & df1 & df2 & Sig. \\
\hline CurrentRatio & 19,182 & 2 & 61 &, 000 \\
\hline ROA &, 015 & 2 & 61 &, 985 \\
\hline ROE & 1,512 & 2 & 61 &, 229 \\
\hline AcidTest & 1,093 & 2 & 61 &, 342 \\
\hline Net Profit Margin & 135,642 & 2 & 61 &, 000 \\
\hline Operating Margin & 138,632 & 2 & 61 &, 000 \\
\hline CFOA &, 884 & 2 & 61 &, 418 \\
\hline Debt To Equity & 1,698 & 2 & 61 &, 192 \\
\hline BIST Sustainability Index & 21,086 & 2 & 61 &, 000 \\
\hline BIST CG Index & 9,636 & 2 & 61 &, 000 \\
\hline
\end{tabular}

Subsequent to significant results are obtained by multivariate tests, for further investigation the test of between subjects effect is employed in relation to each of the dependent variables. The Test of Between- Subjects Effects investigates if there is a significant difference between the means of at least one financial ratio of at least two groups of the transparency levels.

Table 5: Test of Between-Subjects Effect Table

\begin{tabular}{|c|c|c|c|c|c|c|c|}
\hline Source & Dependent Variable & $\begin{array}{l}\text { Type III } \\
\text { Sum of } \\
\text { Squares }\end{array}$ & df & Mean Square & $\mathbf{F}$ & Sig. & $\begin{array}{l}\text { Partial Eta } \\
\text { Squared }\end{array}$ \\
\hline \multirow[t]{10}{*}{ Transparency } & CurrentRatio & 32,149 & 2 & 16,074 & 5,944 & ,004 & 163 \\
\hline & ROA & 115,076 & 2 & 57,538 & ,925 & 402 & 029 \\
\hline & ROE & 1525,387 & 2 & 762,694 & 2,141 & ,126 & 066 \\
\hline & AcidTest & 1,838 & 2 & 919 & ,284 & ,754 & 009 \\
\hline & Net Profit Margin & 8,576 & 2 & 4,288 & 14,107 & 000 & ,316 \\
\hline & Operating Margin & 20,203 & 2 & 10,101 & 13,435 & 000 & ,306 \\
\hline & CFOA & 87,129 & 2 & 43,564 & 4,469 & 015 & ,128 \\
\hline & Debt To Equity & 15202,729 & 2 & 7601,364 & 14,954 & 000 & ,329 \\
\hline & BIST Sustainability Index & 1,751 & 2 & 876 & 3,854 & 027 & ,112 \\
\hline & BIST CG Index & 1,826 & 2 & ,913 & 4,670 & 013 & 133 \\
\hline
\end{tabular}

The results indicate that transparency levels reveal the differences across the financial ratios namely Current Ratio, Net profit Margin, Operating Margin, CFOA to Net Income, Debt to Equity, Sustainability Index Corporate Governance Index for $5 \%$ significance level.

As shown in table 6, for each dependent variable post hoc tests are computed. According to Levene Test, while the error variance of CFOA and Debt to Equity are equal, the rest of them are not. Therefore For CFOA and Debt to Equity Tukey Test, for the other Tamhane Test are considered. After applying Tukey Test, for CFOA, there is a significant difference between third and first, third and second categories for $5 \%$ significance level and for Debt to Equity, there is a significant difference between first and second, first and third categories for $5 \%$ significance level. After results are obtained from Tamhane Test, for Sustainability Index and CG Index there is a significant difference between third and first category and third and second category for $5 \%$ significance level. For the others, there is no significant difference between each category for $5 \%$ significance level. 
Table 6: Multiple Comparisons

\begin{tabular}{|c|c|c|c|c|c|c|c|c|}
\hline \multirow[t]{2}{*}{ Dependent Variable } & & \multirow[t]{2}{*}{ (I) code } & \multirow[t]{2}{*}{ (J) code } & \multirow[t]{2}{*}{$\begin{array}{l}\text { Mean } \\
\text { Difference (I- } \\
\text { J) }\end{array}$} & \multirow[t]{2}{*}{$\begin{array}{l}\text { Std. } \\
\text { Error }\end{array}$} & \multirow[t]{2}{*}{ Sig. } & \multirow{2}{*}{$\begin{array}{l}95 \% \\
\text { Confidence } \\
\text { Interval } \\
\text { Lower } \\
\text { Bound } \\
\end{array}$} & \multirow[b]{2}{*}{$\begin{array}{l}\text { Upper } \\
\text { Bound }\end{array}$} \\
\hline & & & & & & & & \\
\hline \multirow[t]{12}{*}{ CFOA } & \multirow[t]{6}{*}{ Tukey HSD } & Low & Medium &, 028 & ,808 & ,999 & $-1,914$ & 1,969 \\
\hline & & & High & $-5,504$ & 1,904 & ,014 & $-10,077$ & $-0,931$ \\
\hline & & Medium & Low &,- 028 & 808 & ,999 & $-1,969$ & 1,914 \\
\hline & & & High & $-5,531$ & 1,878 & ,013 & $-10,043$ & $-1,020$ \\
\hline & & High & Low & 5,504 & 1,904 & ,014 & 0,931 & 10,077 \\
\hline & & & Medium & 5,531 & 1,878 & ,013 & 1,020 & 10,043 \\
\hline & \multirow[t]{6}{*}{ Tamhane } & Low & Medium & ,028 & ,787 & 1,000 & $-1,914$ & 1,969 \\
\hline & & & High & $-5,504$ & 3,222 & ,527 & $-27,593$ & 16,585 \\
\hline & & Medium & Low &,- 028 & ,787 & 1,000 & $-1,969$ & 1,914 \\
\hline & & & High & $-5,531$ & 3,201 &, 526 & $-28,228$ & 17,165 \\
\hline & & High & Low & 5,504 & 3,222 & ,527 & $-16,585$ & 27,593 \\
\hline & & & Medium & 5,531 & 3,201 & ,526 & $-17,165$ & 28,228 \\
\hline \multirow[t]{12}{*}{ Debt To Equity } & \multirow[t]{6}{*}{ Tukey HSD } & Low & Medium & $-28,837$ & 5,837 & ,000 & $-42,859$ & $-14,815$ \\
\hline & & & High & $-47,824$ & 13,747 & ,003 & $-80,848$ & $-14,800$ \\
\hline & & Medium & Low & 28,837 & 5,837 & ,000 & 14,815 & 42,859 \\
\hline & & & High & $-18,987$ & 13,563 & 347 & $-51,568$ & 13,595 \\
\hline & & High & Low & 47,824 & 13,747 & ,003 & 14,800 & 80,848 \\
\hline & & & Medium & 18,987 & 13,563 & 347 & $-13,595$ & 51,568 \\
\hline & \multirow[t]{6}{*}{ Tamhane } & Low & Medium & $-28,837$ & 6,152 & ,000 & $-44,088$ & $-13,586$ \\
\hline & & & High & $-47,824$ & 7,064 & ,000 & $-68,977$ & $-26,671$ \\
\hline & & Medium & Low & 28,837 & 6,152 & ,000 & 13,586 & 44,088 \\
\hline & & & High & $-18,987$ & 5,936 & ,084 & $-41,236$ & 3,262 \\
\hline & & High & Low & 47,824 & 7,064 & ,000 & 26,671 & 68,977 \\
\hline & & & Medium & 18,987 & 5,936 & 084 & $-3,262$ & 41,236 \\
\hline \multirow[t]{12}{*}{ BIST Sustainability Index } & \multirow[t]{6}{*}{ Tukey HSD } & Low & Medium &,- 216 & ,1234 & ,194 &,- 513 & ,080 \\
\hline & & & High &,- 731 & ,2906 & 038 & $-1,429$ &,- 033 \\
\hline & & Medium & Low & ,216 & ,1234 & ,194 &,- 080 & ,513 \\
\hline & & & High &,- 514 & ,2867 & 180 & $-1,203$ &, 175 \\
\hline & & High & Low & ,731 & ,2906 & ,038 & 033 & 1,429 \\
\hline & & & Medium & ,514 & ,2867 & 180 &,- 175 & 1,203 \\
\hline & \multirow[t]{6}{*}{ Tamhane } & Low & Medium &,- 216 & 1234 & ,233 &,- 520 & ,087 \\
\hline & & & High &,- 731 & ,0887 & , 000 &,- 958 &,- 504 \\
\hline & & Medium & Low &, 216 & ,1234 & ,233 &,- 087 &, 520 \\
\hline & & & High &,- 514 & ,0857 & ,000 &,- 730 &,- 299 \\
\hline & & High & Low & ,731 & ,0887 & ,000 & ,504 & ,958 \\
\hline & & & Medium & ,514 & ,0857 & ,000 & ,299 & ,730 \\
\hline \multirow[t]{12}{*}{ BIST CG Index } & \multirow[t]{6}{*}{ Tukey HSD } & Low & Medium &,- 151 & ,1145 & ,392 &,- 426 & ,124 \\
\hline & & & High &,- 808 & ,2696 & ,011 & $-1,455$ &,- 160 \\
\hline & & Medium & Low & ,151 & ,1145 & ,392 &,- 124 & ,426 \\
\hline & & & High &,- 657 & ,2660 & ,042 & $-1,296$ &,- 018 \\
\hline & & High & Low & 808 & ,2696 & ,011 & 160 & 1,455 \\
\hline & & & Medium & ,657 & ,2660 & ,042 & ,018 & 1,296 \\
\hline & \multirow[t]{6}{*}{ Tamhane } & Low & Medium &,- 151 & ,1133 & ,467 &,- 429 & ,128 \\
\hline & & & High &,- 808 & ,0788 & ,000 & $-1,009$ &,- 606 \\
\hline & & Medium & Low & 151 & ,1133 & ,467 &,- 128 &, 429 \\
\hline & & & High &,- 657 & ,0814 & ,000 &,- 862 &,- 453 \\
\hline & & High & Low & ,808 & ,0788 & ,000 & ,606 & 1,009 \\
\hline & & & Medium & ,657 & ,0814 & ,000 & ,453 & 862 \\
\hline
\end{tabular}




\section{CONCLUSION}

The purpose of this paper is to examine the relationship between the transparency level and the financial performance indicators of 64 manufacturing companies which are listed in BIST-100 index during the year 2016. Initially, the transparency levels of financial information disclosures in annual reports are calculated by establishing a transparency checklist for the year 2016. After calculating this transparency level scores of 64 companies, these companies are divided into 3 categories which are previously mentioned in this study.

MANOVA analysis is used to test the relationship between the transparency level and the financial performance indicators. The results indicated that transparency level has statistically significant effect between the group means of four variables. These are CFOA to Net Income, Debt to Equity, Sustainability Index and Corporate Governance Index.

- For Debt to Equity ratio variable; there is a significant difference between first and second category and first and third category for $5 \%$ significance level. The mean of the first group is smaller than the second and third one.

- For CFOA/Net Income ratio variable; there is a significant difference between third and first category and third and second category for $5 \%$ significance level. The mean of the third group is greater than the first and second one.

- For Sustainability Index and CG Index there is a significant difference between third and first category and third and second category for $5 \%$ significance level. The mean of the third group is greater than the first and second one.

For further researches, financial performance indicators and criterias in transparency disclosure checlist can be developed. In this study, only transparency of the financial information disclosure is examined. It can be also generalized for all Transparency and Disclosure issues. To attain more financial information disclosure for Turkish market, all companies listed in BIST can be added to sample of the study.

\section{REFERENCES}

Achoki, I., Kule, J., Shukla, J. (2016). Effect of voluntary disclosure on the financial performance of commercial banks in Rwanda. A study on selected banks in Rwanda. European Journal of Business and Social Sciences, September, Vol. 5, No. 6, p.167-184.

Adiloglu, B., Vuran, B. (2012). The relationship between the financial ratios and transparency levels of financial information disclosures within the scope of corporate governance: evidence from Turkey. The Journal of Applied Business Research, vol. 28, no. 4, p. 543-554.

Akhigbe A., McNulty J. E., Stevenson B. A. (2017). Additional evidence on transparency and bank financial performance. Review of Financial Economics, 32, p. 1-6.

Aksu, M., Kösedağ, A. (2006). Transparency and disclosure scores and their determinants in the Istanbul Stock Exchange. Corporate Governance: An International Review, vol.14, no. 4, p. 277-296.

Arbatlı, E., Escolano, J. (2015). Fiscal transparency, fiscal performance and credit ratings. Fiscal Studies, vol. 36, no. 2, pp. 237-270

Haat, C., Rahman, A., Mahenthiran, S. (2008). Corporate governance, transparency and performance of Malaysian companies. Managerial Auditing Journal, Vol. 23 No. 8, p. 744-778

Hadi, A., Handajani, L., Putra, I. (2018). Financial disclosure based on Web-ICT determinants. International Research Journal Of Management, IT \& Social Sciences, 5(1), p. 72-85.

Madhani, P. M. (2007). Role of voluntary disclosure and transparency in financial reporting. The Accounting World, vol. 7, no. 6, p. 63-66

Patel, S., Dallas, G. (2002). Transparency and disclosure: overview of methodology and study results-United States. Working paper, Standard and Poor's and SSRN.

OECD. (1998). Business Sector Advisory Group on Corporate Governance. Corporate Governance: Improving Competitiveness and Access to Capital in Global Markets.

Qiu, Y., Shaukat, A., Tharyan, R. (2016). Environmental and social disclosures: link with corporate financial performance. The British Accounting Review, vol. 48, no. 1 p. 102-116.

Sharif, S. P., Ming Lai, M. M. (2015). The effects of corporate disclosure practices on firm performance, risk and dividend policy. International Journal of Disclosure and Governance, vol. 12, no. 4 p. 311-326.

Tabachnick, B. G., Fidell, L. S. (2007). Using multivariate statistics, 6.th ed. Pearson Educat ion Limited, Essex.

Torchia, M., Calabrò, A. (2016). Board of directors and financial transparency and disclosure. Evidence from Italy. Corporate Governance: The International Journal of Business in Society, Vol. 16 Iss 3 p. 593-608.

Zulfikar, R., May, N., Suhardjanto, D., Agustiningsih, S. W. (2017). Independent commissioner against mandatory disclosure of financial performance as a moderating variable. Review of Integrative Busines Economics Research, vol. 6, no. 3, p.205-216. 